\title{
Significant Changes Experienced by Adopters of Sustainable Organic Agriculture Technologies in Ormoc City, Philippines
}

\author{
Catherine L. Corcino ${ }^{1}$ and Editha G. Cagasan ${ }^{2}$ \\ 'Visayas State University - Isabel Campus, Isabel, Leyte, Philippines; '2Department of \\ Development Communication, Visayas State University - Main Campus, Baybay City, \\ Leyte 6521-A, Philippines
}

\begin{abstract}
In an effort to help preserve the environment, several organizations have been promoting the use of sustainable organic agriculture (SOA) technologies. Many farmers have already tried adopting one or a combination of these technologies. This study was conducted in Ormoc City, Leyte, Philippines to determine the changes experienced by farmers after adopting the SOA technologies introduced to them by the Rural Development Institute in Leyte, Philippines (RDI-Leyte). Data were gathered through in-depth interviews with 30 farmer-adopters in seven villages of the city. To determine significant changes experienced by the farmer-adopters, significant change stories were collected and reviewed following the procedures of the Most Significant Change (MSC) technique outlined by Davies and Dart (2005).

Analysis of the MSC stories revealed that there were three kinds of changes experienced by the technology adopters. These include improved knowledge and skills on organic farming systems, improved food quality, and improved economic conditions. These changes correspond to the objectives of RDI-Leyte in their advocacy on SOA technologies and to higher levels (i.e., levels 5 to 7) in Bennett's hierarchy of program outcomes. This suggests that the efforts of RDI-Leyte to promote SOA technologies have already made some impacts on the technology adopters' lives.
\end{abstract}

Keywords: technology adoption, information dissemination, program impacts, Leyte

Correspondence: Dr. Editha G. Cagasan Address: Department of Development Communication, Visayas State University, Baybay City, Leyte, 6521-A Philippines. Tel: (053) 335-2650 E-mail: edithcagasan@yahoo.com

DOI: $10.32945 /$ atr3328.2011 


\section{INTRODUCTION}

Communication plays a vital role in the day-to-day undertakings of people. It provides information on available technology which is vital for social change. It also allows people in the community to be heard and to engage in making decisions that enhance their lives (Dagron, 2001). In the context of agriculture, communication is necessary to change farmers' behavior in relation to the use of technologies that can improve farm productivity.

At present, one agricultural practice that is introduced to farmers is organic farming. It has been promoted basically because it is not harmful to the environment. It discourages farmers to use synthetic chemicals, so it has the potential to contribute to agricultural sustainability. In the Philippines, organic farming methods are used by farmers who do not have the capital to acquire synthetic products. It is accepted by the people as they become more alarmed of the harmful effects of chemicals found on the food produced using high volume of chemicals and inorganic fertilizers (Cabangisan, 2007).

Convinced by the advantages of organic farming, many development organizations have exerted efforts to persuade farmers to adopt sustainable organic agriculture technology (SOA). One group of advocates that introduced sustainable organic agriculture technology to the farmers is the Rural Development Institute in Leyte, Philippines (RDI-Leyte), a non-government organization which became part of the Eastern Visayas Sustainable Organic Agriculture Network (EVSOANet) in 2005. In SOA practice, farmers are encouraged to minimize the use of chemical fertilizers and pesticides. The SOA technologies introduced by RDI to farmers include combinations of natural farming system and low external inputs sustainable agriculture (NFS-LEISA); natural farming inputs and low external inputs sustainable agriculture (NFI-LEISA); modified system on rice intensification (SRI) and rice duck integration; natural farming system (NFS), and vermi-composting. RDI-Leyte had already trained 298 farmers on these technologies. Of these, 43 were reported to have adopted one or a combination of the abovementioned technologies. However, there are no studies yet that assessed the impact of these technologies to the farmer-adopters. 
This study was conducted to determine the changes experienced and considered important by the farmers who adopted the SOA technologies. But instead of assessing technology impacts using pre-identified quantitative impact indicators, this study used a new participatory monitoring and evaluation (PM\&E) approach known as the Most Significant Change (MSC) Technique (Davies and Dart, 2005). As described by Dart (1999), this technique involves the collection of significant change stories from project stakeholders and the systematic review and selection of the most significant stories by panels of designated stakeholders. Davies and Dart (2005) explained that the MSC technique is appropriate when project or program implementers are interested on the effects of an intervention in people's lives and wish to include the words of non-professionals. They added that MSC is useful in identifying unexpected impacts of interventions, in helping stakeholders to notice events considered important by the clientele, and to help realign efforts towards achieving more of the 'wonderful things' and less of the 'terrible things'. Those who have tried using the approach found it very useful in facilitating dialogue among project stakeholders about the outcomes of development programs (Davies, 1998; Dart, 2000; Le Cornu et al., 2003; Ringsing, 2003; Velarde et al., 2007; Cagasan and Velasco, 2009).

\section{MATERIALS AND METHODS}

\section{Locale and Respondents of the Study}

This study was conducted in seven villages of Ormoc City, Leyte, Philippines (Figures 1a and 1b) where the RDI-Leyte technicians introduced the SOA technologies. These villages include Guintigui-an, Labrador, Libertad, Lilo-an, Matica-a, Sabang Bao and San Jose. These are agricultural villages where farmers grow various crops including rice, coconut, sugarcane and vegetables (most commonly eggplant, bitter gourd, tomatoes and string beans). These can be reached through motorcycles and multicabs. 
Data were gathered through in-depth interviews with farmers who adopted at least one or a combination of the SOA technologies for more than a year. At the time of this study, there were 30 farmers who satisfied this criterion, and all of them were taken as informants of this study.

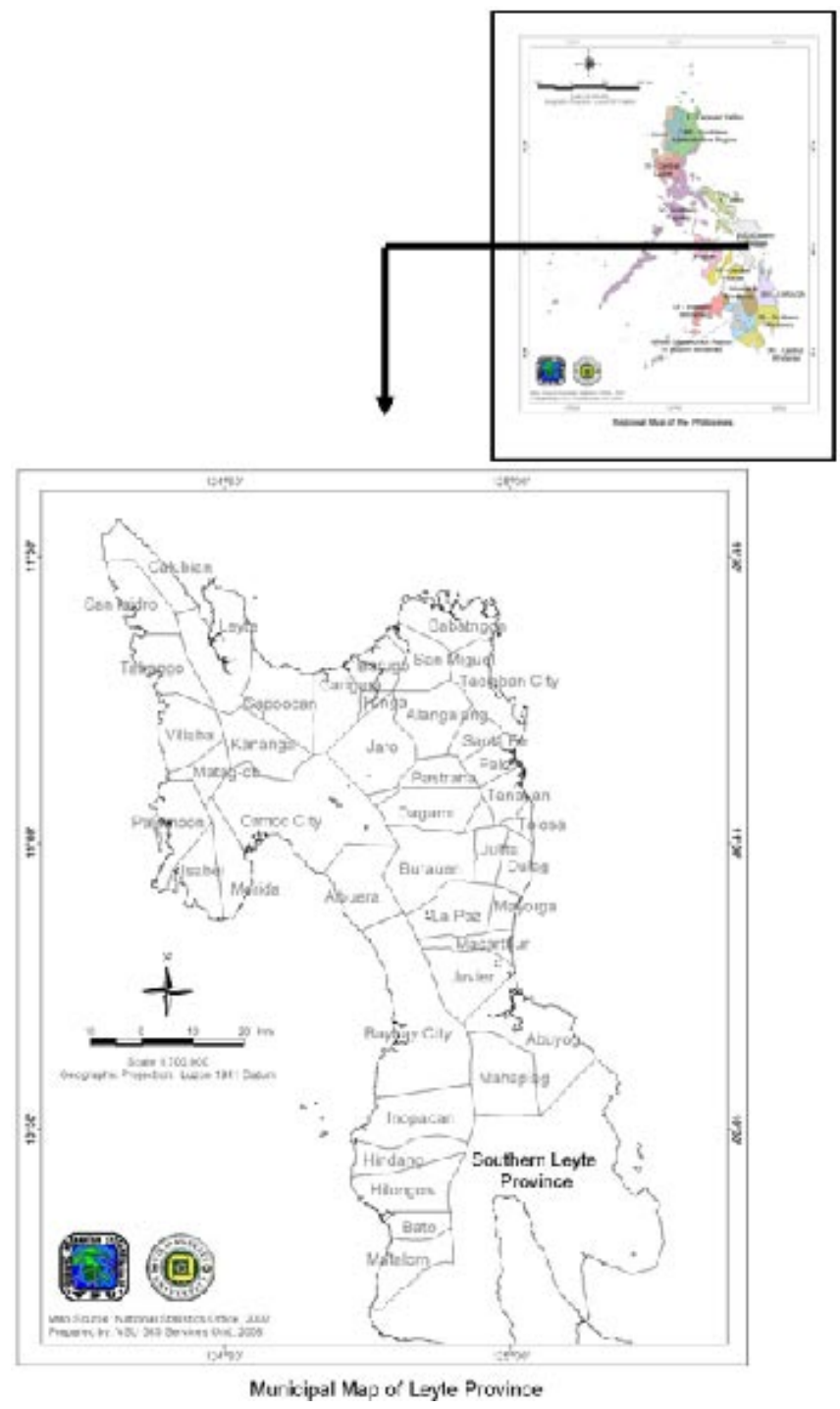

Figure 1a. Map of Leyte, Philippines showing the study site, Ormoc City. 


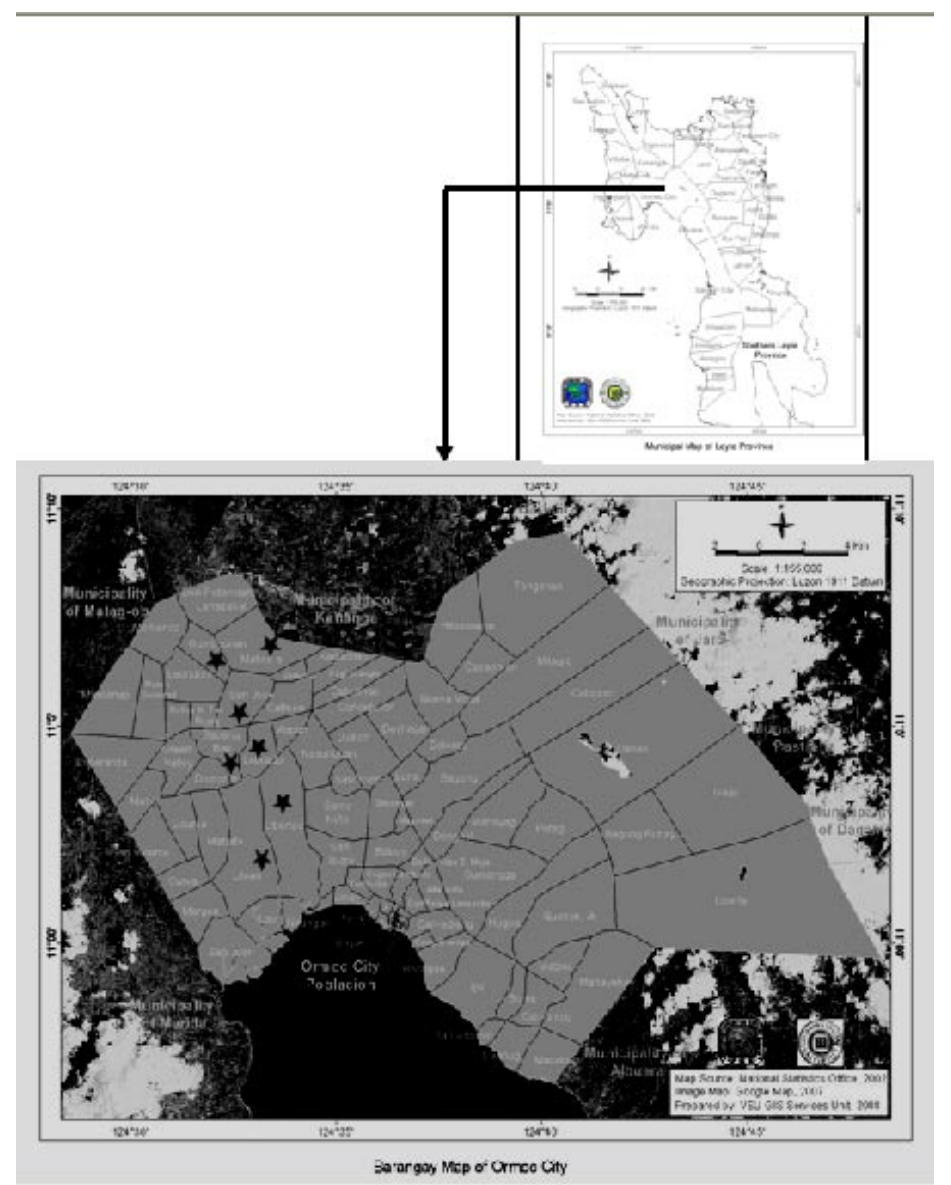

Figure 1b. Map of Ormoc City showing the seven study barangays.

\section{Data Collection Procedure}

Before gathering data about the changes experienced by technology adopters, the researchers first interviewed the RDI-Leyte staff to get information about the SOA technologies they introduced to farmers. More information were also gathered from reports prepared by the RDILeyte staff.

To determine significant changes experienced by the farmers after adopting the technology, the researchers adapted the MSC procedures outlined by Davis and Dart (2005). Full implementation of the MSC 
process involves 10 steps described in Box 1. But according to Davies and Dart (2005), organizations that would want to use MSC can modify the process to suit the context of the program to be monitored and evaluated.

For this study, the process of collecting and selecting significant change stories, and the sending of feedback to different groups of stakeholders, is summarized in Figure 2. The researchers gathered the stories through in-depth interviews with the farmer-adopters. The farmers' accounts were recorded using an MP3 recorder and were later translated in toto. The stories were then compiled for thematic analysis and submitted to the RDI-Leyte staff for review and selection of the changes considered most significant.

Box 1. Steps in the MSC Process Implementation

(Davies and Dart, 2005; http://www.healthcomms.org):

1. Raising interest - This involves introducing a range of stakeholders to MSC and fostering interest and commitment to participate.

2. Defining the domains of change - selected stakeholders identify broad domains (i.e., changes in people's lives) that are not precisely defined like performance indicators, but are deliberately left loose, to be defined by the actual users.

3. Defining the reporting period - Stakeholders decide how frequently to monitor changes taking place in the selected domains.

4. Collecting SC stories - Stories of Change (SC) stories are collected from those most directly involved, such as participants and field staff. The stories are collected by asking a simple question such as: 'During the last month, in your opinion, what was the most significant change that took place for participants in the program? The respondents are also encouraged to report why they consider a particular change to be the most significant.

5. Selecting the most significant of the stories - the stories are then analyzed and filtered up through the levels of authority 
typically found within an organization or program. Each level of the hierarchy reviews a series of stories sent to them by the level below and selects the single most significant account of change within each of the domains. Each group then sends the selected stories up to the next level of the program hierarchy, and the number of stories is reduced through a systematic and transparent process.

6. Feeding back the results of the selection process - Every time stories are selected, the criteria used to select them are recorded and fed back to all interested stakeholders, so that each subsequent round of story collection and selection is informed by feedback from previous rounds. After this process has been used for some time, a document is produced with all stories selected at the uppermost organizational level over that period in each domain of change. The stories are accompanied by the reasons the stories were selected. The program funders are asked to assess the stories in this document and select those that best represent the sort of outcomes they wish to fund. They are also asked to document the reasons for their choice. This information is fed back to project managers.

7. Verification of the SC stories - The selected stories can be verified by visiting the sites where the described events took place. This is to check that stories have been reported accurately and honestly, and to provide an opportunity to gather more detailed information about events seen as significant. A visit also offers a chance to see what has happened since the event was first documented.

8. Quantification - When an account of change is first described, it is possible to include quantitative as well as qualitative information. It is also possible to quantify the extent to which the most significant changes identified in one location have taken place in other locations within a specific period.

9. Secondary analysis and meta-monitoring - Secondary analysis involves in-depth examination and analysis of the content of the selected stories (what types of changes are valued by the different 
stakeholders, etc.), while meta-motoring means monitoring the M\& E system itself. This can include looking at who participated and how they affected the contents, and analyzing how often different types of changes are reported.

10. Revising the system - Considering what has been learned as a direct result of using it and from analyzing its use, the MSC process may be revised to suit the context of the program to be monitored and evaluated.

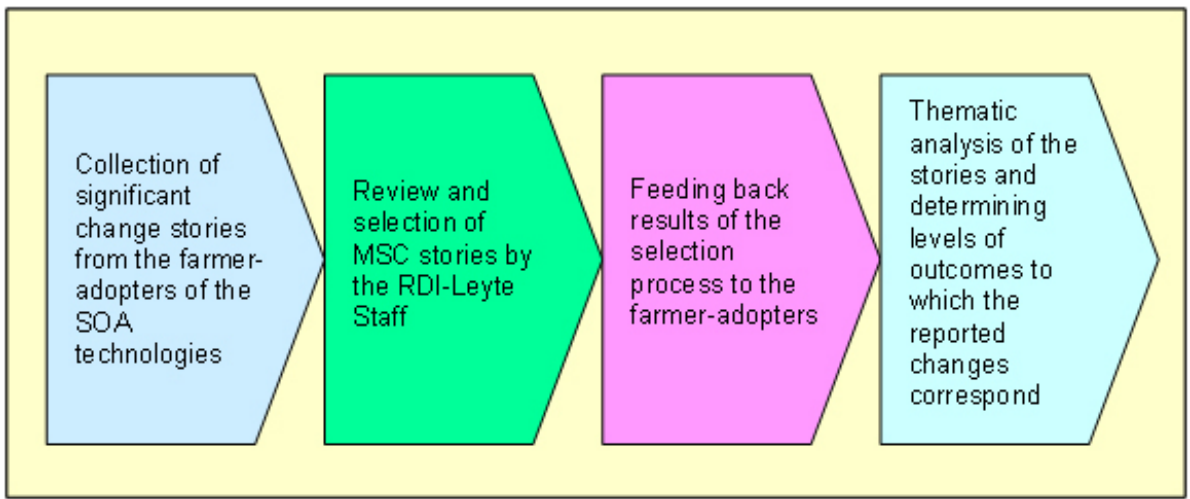

Fig. 2. Process of collecting and selecting significant change stories and the sending of feedback to farmer-adopters

Analysis of the Collected Stories

A total of 30 significant change stories (i.e., stories about changes considered significant or important by the storytellers) were collected by the researchers. However, only 24 were used in the thematic analysis because the changes reported in the other six stories could not be directly attributed to the RDI's efforts.

To establish the domains of change represented by the various stories, a meeting with the researcher, three staff of RDI-Leyte and the SOA training consultant was conducted. Prior to the meeting, the participants of the review and selection process were given copies of the significant change stories. During the meeting they were requested to read the stories. After they had read the stories, they were asked to categorize the type of changes experienced by the farmers. 
To identify the kinds of change most valued by the RDI-Leyte staff, they were asked to select one story per domain, which they thought represents the kind of change they would want their clientele to experience.

To determine the levels of project outcomes to which the reported changes correspond, the themes of changes identified were classified based on Bennett's Hierarchy of Program Evidence (Table 1; adapted from Van den Ban and Hawkins, 1996).

Table 1. Levels for judging outcomes of an extension or development program

\begin{tabular}{|c|c|}
\hline Level & Description \\
\hline 8 & $\begin{array}{l}\text { Consequences for society (Example: availability of organic produce such } \\
\text { as rice and vegetable in the market; less polluted rivers; availability of } \\
\text { organic fertilizers to other farmers, etc.) }\end{array}$ \\
\hline 7 & $\begin{array}{l}\text { Consequences for the target group (Example: lesser farm expenses, higher } \\
\text { yield, higher income, etc.) }\end{array}$ \\
\hline 6 & $\begin{array}{l}\text { Behavioral changes in the target group (Example: change in farm practices } \\
\text { from synthetic-base farming systems into organic farming systems, or a } \\
\text { combination of organic and inorganic farm practices, etc.) }\end{array}$ \\
\hline 5 & $\begin{array}{l}\text { Changes in knowledge, attitude, skills, motivation and group norms } \\
\text { (Example: change in perception with regards to food security and } \\
\text { environmental safety, increased knowledge about the helpful insects in the } \\
\text { farm, acquired knowledge and skills in making organic fertilizers, etc.) }\end{array}$ \\
\hline 4 & $\begin{array}{l}\text { The farmers' opinion in extension activities (Example: increase number of } \\
\text { technology adopters, etc.) }\end{array}$ \\
\hline 3 & $\begin{array}{l}\text { Farmers' participation in extension activities: (Example: increase in the } \\
\text { number of farmers who participated in any extension activities conducted } \\
\text { by RDI-Leyte, increased number of demo farms, etc.) }\end{array}$ \\
\hline 2 & $\begin{array}{l}\text { Implementation of the program by extension agents (Example: frequent } \\
\text { meetings done by extension agents, increase number of extension agents } \\
\text { deployed in the field for IEC campaign, seminar workshops and others, } \\
\text { etc.) }\end{array}$ \\
\hline 1 & $\begin{array}{l}\text { Programming of the extension activities (Example: scheduling of extension } \\
\text { activities in various villages in Ormoc City, increased number of villages } \\
\text { to be visited by extension agents, designing different communication } \\
\text { activities for different clientele, etc.) }\end{array}$ \\
\hline
\end{tabular}




\section{RESULTS AND DISCUSSION}

\section{Profile of the Respondents}

The RDI staff-respondents included four Local Economic Development Facilitators, one executive director and one support staff. All of them were middle-aged. Five were female and married, and four were graduates of Bachelor of Science in Agriculture.

The 30 adopter-respondents, on the other hand, had ages ranging from 22-63 years. More than half of them (16) were old (46-60 years old); the others were middle-aged (10) and senior citizen (4). Sixteen were male and the rest (14) were female. Most (26) of the respondents depended on farming as their main source of livelihood. All of them were members of the farmers' associations organized by RDI-Leyte.

\section{Technologies Introduced by RDI-Leyte to Farmers}

Interview with the RDI-Leyte staff revealed that the organization introduced a total of five SOA technologies to farmers. These technologies included combinations of natural farming system and low external inputs sustainable agriculture (NFS-LEISA); natural farming inputs and low external inputs sustainable agriculture (NFI-LEISA); modified system on rice intensification (SRI) and rice duck integration; natural farming system (NFS), and vermi-composting. The descriptions of these technologies are presented in Table 2.

\section{Changes Experienced and Perceived as Significant by Farmer- Adopters}

The changes experienced by farmer-adopters were classified by the story reviewers into three domains, namely: 1) improvement in knowledge and skills on organic farming, 2) food quality improvement, and 3) economic improvement. Four stories were classified under improvement in knowledge and skills on organic farming systems, seven 
Table 2. The SOA technologies promoted by RDI-Leyte.

\begin{tabular}{|c|c|}
\hline SOA Technologies & Description \\
\hline $\begin{array}{l}\text { NFS-LEISA (Natural Farming } \\
\text { System- Low External Input } \\
\text { Sustainable Agriculture) }\end{array}$ & $\begin{array}{l}\text { A farming system that uses a minimum amount of } \\
\text { commercial inorganic fertilizers and chemical pesticides. }\end{array}$ \\
\hline $\begin{array}{l}\text { NFI-LEISA (Natural Farming } \\
\text { Inputs- Low External Input } \\
\text { Sustainable Agriculture) }\end{array}$ & $\begin{array}{l}\text { A farming method that uses the locally produced natural } \\
\text { fertilizers such as Oriental Herbal Nutrient (OHN), } \\
\text { Fermented Fruit Juice (FFJ), Fermented Plant Juice (FPJ), } \\
\text { Fish Amino Acid (FAA), Indigenous Micro-organism } \\
\text { (IMO), Lactic Acid Syrum (LAS), Calcium Phosphate } \\
\text { (CP) and Garbage Juice (GJ), in combination with a } \\
\text { minimum amount of commercial inorganic fertilizers and } \\
\text { pesticides. }\end{array}$ \\
\hline Modified SRI - rice duck integration & $\begin{array}{l}\text { A rice production technology that uses system on rice } \\
\text { intensification (SRI) practices and integration of ducks in } \\
\text { the farming system. SRI is a system of rice planting that } \\
\text { uses only one seedling per hill planted in a wider distance } \\
\text { of about } 10-12 \text { inches between hills and between rows, } \\
\text { minimum irrigation water, and organic fertilizers. }\end{array}$ \\
\hline Natural Farming System (NFS) & $\begin{array}{l}\text { Discourages burning of crop residues. Instead, it } \\
\text { encourages the use of indigenous materials and beneficial } \\
\text { micro-organisms in the production of organic fertilizers } \\
\text { and botanical pesticides. }\end{array}$ \\
\hline Vermi-composting & $\begin{array}{l}\text { The production of organic fertilizers using vermicast } \\
\text { (earthworm castings) as the main ingredient. }\end{array}$ \\
\hline
\end{tabular}

were under food quality improvement, and 13 were under economic improvement (Table 3).

Knowledge and skills improvement. The four stories under this domain were about the farmers' modification of farm practices they learned about organic farming systems, and their improved knowledge and skills to identify helpful and harmful insects in the farm.

a. Change in Farm Practice. According to the farmers, after learning about the SOA, they changed their farming practices because they realized that commercial inorganic fertilizers could deplete the nutrients found in the soil causing it to be acidic and unproductive. Constant use of organic fertilizers in their farms, they said, could restore soil fertility and productivity. According to one farmer respondent:

... through the trainings conducted by RDI, we learned to use organic fertilizers which sustain soil fertility in our farm. 
Table 3. Domains and themes of the significant change stories collected from the farmer-adopters

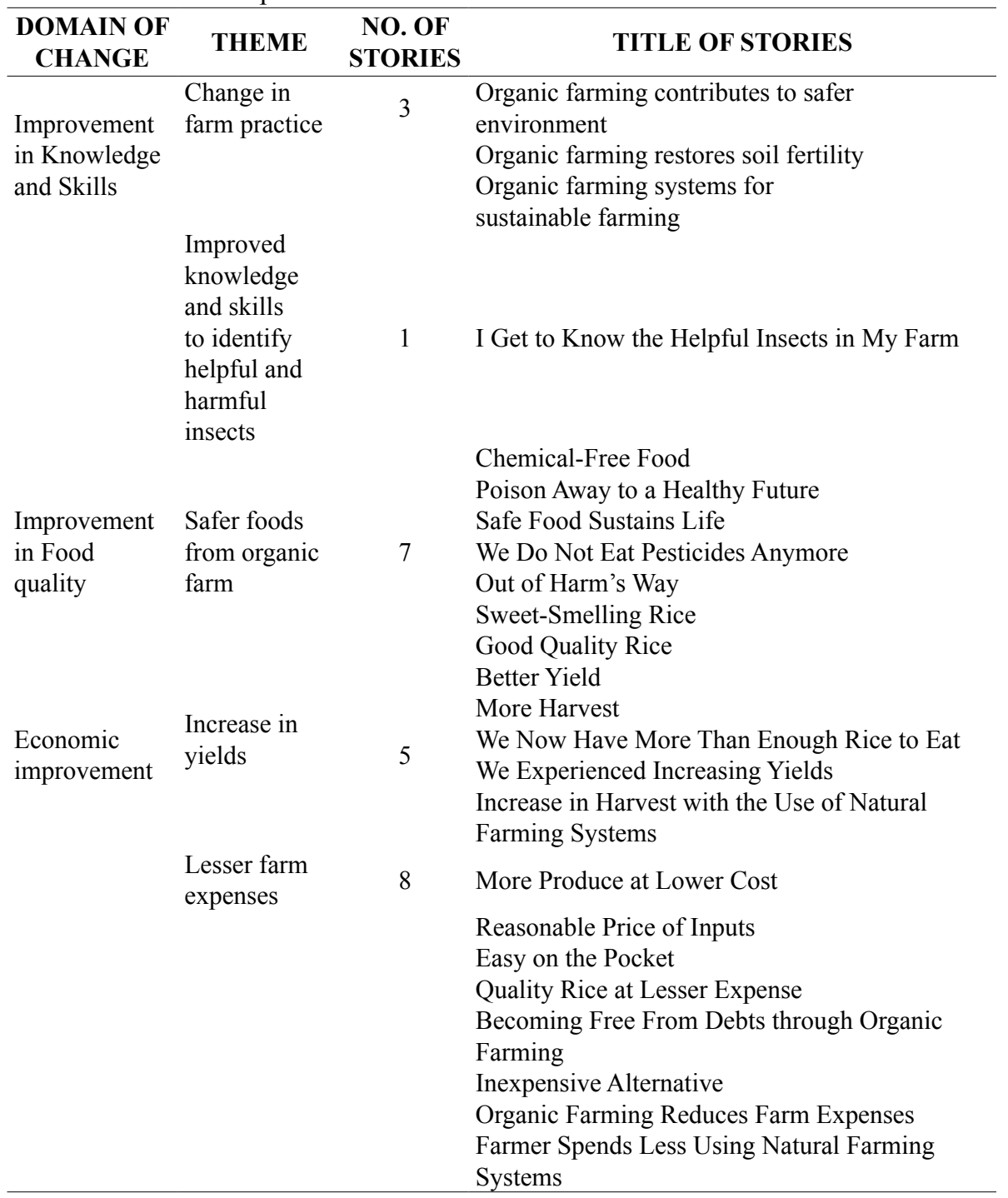

Aside from that, our environment is now becoming safer; the animals, the fishes, and the people will be safe too because we no longer use harmful chemicals in our farm. For me, this is the most important change that I experienced in using this technology. 
b. Improved knowledge and skills to identify helpful and harmful insects on the farm. According to the farmer-adopters, after participating in the trainings conducted by RDI, they learned to identify helpful insects found in their farm. They also realized that by using SOA technologies they can preserve these helpful insects. One farmer said:

...the technology that I learned from the training conducted by RDI-Leyte staff increased my ability to recognize helpful and harmful insects in my farm. For me it is important to identify those insects so that I would not use chemicals that could kill the helpful ones.

Food quality improvement. The changes classified under this domain were about developing positive perception about the quality of food that are organically grown. According to the story tellers, they feel that they are healthier now because the foods they eat no longer contain harmful chemicals. According to one farmer-respondent:

... for me the most significant change that I experienced after using organic method of farming is the feeling that our food is now safer because it comes from our organic farm. For me that is the most important because my family will be safe and with God's mercy my family will be free from sickness.

Economic improvement. The 13 stories under this domain referred to two types of changes, namely increase in yields and lesser farm expenses.

a. Increase in yields. According to the farmers interviewed, when they first applied organic fertilizers in their farms, the crop yields decreased. However, when they constantly used the organic fertilizers, their yields, as well as the buying price of their produce increased. According to one farmer:

My yield increased when I used organic farming method. I was even able to sell some of my harvest because we could not consume all of it anymore. Because of that, I also earned money unlike before when I always bought rice in the market and I was worried every time I saw that there was almost nothing left in our container. But now (laughing), what I am worried about is when it rains, nobody can help us gather the dried palay since 
we have no children, there is just the two of us.

b. Lesser farm expenses. According to the farmers, buying expensive commercial fertilizers, pesticides and insecticides is a burden for them because they lack money for such additional expenses. So, they were happy when they were given cheaper alternative through the use of organic farming technique. According to one lady farmer:

I am now using foliar fertilizers made from seaweeds, banana shoots, bones and gills of fish, and OHN like garlic, onions and lemon grass. In making foliar fertilizers, the ratio is always 1:1. For instance, 1 kilo of seaweed is mixed with 1 kilo of molasses. To drive away insects I use leaves of madre de cacao. I am still using these technologies on my farm until now because these are cheaper and the ingredients are available in our locality.

In summary, the above results indicate that the efforts exerted by RDI-Leyte in promoting SOA technologies to farmers led to the adoption of some new technologies by some farmers. Technology adoption consequently resulted in changes related to the improvement in the quality of their food and their economic conditions. These changes, according to the RDI-Leyte staff, are in line with the goals of RDILeyte.

\section{Levels of Outcomes}

Data showed that the changes experienced by the farmers after adopting SOA technologies correspond to higher levels of program outcomes (i.e., levels 6-7 in Bennett's hierarchy shown in Table 4). Twenty of the 24 stories were about changes in the conditions of the farmer-adopters (level 7). This means that the efforts of RDI-Leyte had already made some impacts on the lives of the intended beneficiaries.

Stories selected by the RDI staff as most significant

The story entitled "Organic Farming Contributes to Safer Environment" was chosen as the best story among the three stories telling 
Table 4. Levels of project outcomes to which the reported changes correspond

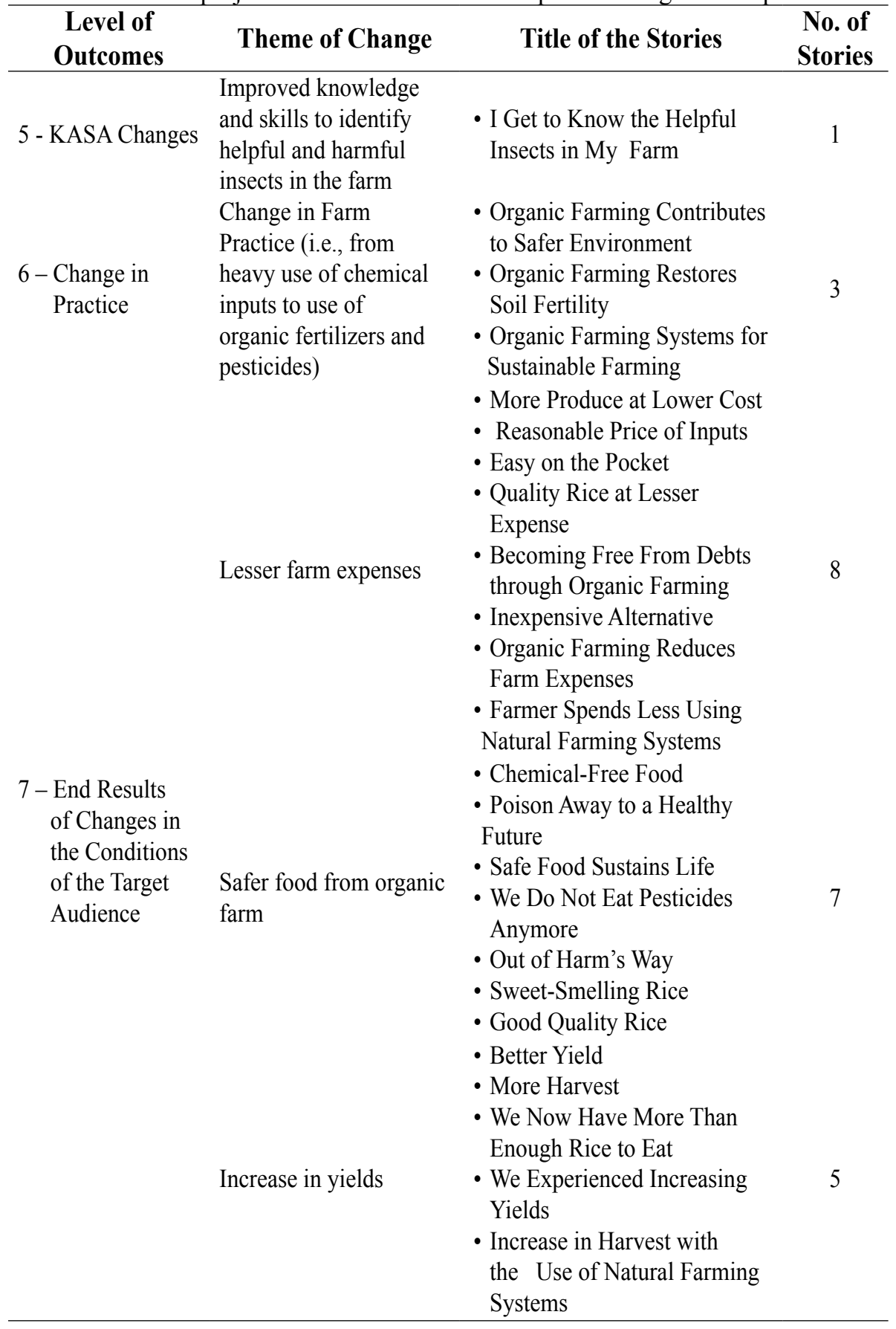


about the impacts of gaining knowledge and skills on organic farming systems. According to the reviewers, this story conveys a picture of a better environment because of the rehabilitation of soil without using inorganic fertilizers.

The story of a lady farmer entitled "Poison Away to a Healthy Future" was chosen as the most significant story from among the seven stories telling about improvement in food quality. The RDI staff members who reviewed the stories said that they chose her story because it did not only tell about increase in production, but it also revealed the storytellers' realization that the use of SOA technology could give safer food for her family.

On the other hand, among the 13 stories about economic changes, the story entitled "Organic Farming Reduces Farm Expenses" was chosen as the most significant. The evaluators selected the story because they felt it was not only about large savings obtained from using natural farm inputs, but also how the storyteller shared the technology with other farmers by selling some of the natural inputs he made to them.

The selected stories and the RDI officers' reasons for choosing them are presented in Table 5.

\section{IMPLICATIONS AND RECOMMENDATIONS}

The study revealed that adoption of SOA technologies had already caused significant changes in the lives of the farmer-adopters. As revealed in the thematic analysis, these changes were about improvements in the knowledge and skills on organic farming systems, food quality and economic conditions of the farmers. However, these changes were only experienced by farmers who adopted the technology and based on the RDI records; there were only 43 farmers who adopted the technology. If the SOA advocates want to extend the benefits of technology adoption to more people, they need to strengthen their promotion and advocacy efforts. To increase the likelihood of the SOA technologies to fit the conditions of farmers, SOA advocates may need to involve the farmers themselves in the development and promotion of SOA technologies. 
Table 5. Stories selected by the RDI staff as the most significant and their reasons for selecting the stories

\begin{tabular}{ccc}
\hline DOMAIN OF & TITLE OF THE & REVIEWERS' COMMENTS \\
CHANGE & STORY & \\
\hline
\end{tabular}

$\begin{array}{ll} & \begin{array}{l}\text { Organic Farming } \\ \text { Contributes }\end{array} \\ \text { Knowledge } & \begin{array}{l}\text { to Safer } \\ \text { and Skills }\end{array} \\ \text { Improvement } & \text { Environment }\end{array}$

The farmer reported that because of shifting his farming systems to organic method, he experienced food security not only in quantity but also in quality. He does not spray anymore insecticides in his farm in that way the helpful insects will be protected. He observed that his crops are resistant to pest and diseases and his farm has transformed from infertile to fertile farm.

$\begin{array}{lll}\text { Food Quality } & \begin{array}{l}\text { Poison Away } \\ \text { to a Healthy }\end{array} & \begin{array}{l}\text { Aside from observed increase in rice } \\ \text { production, the farmer is proud to tell the } \\ \text { researcher that the rice that his family eats is } \\ \text { free from poison. She is convinced that food } \\ \text { free from chemicals protects his family from } \\ \text { illness. }\end{array} \\ \begin{array}{l}\text { Future (by a lady } \\ \text { farmer) }\end{array} & \begin{array}{l}\text { Like the others, the farmer experienced big } \\ \text { savings when he used natural farm inputs. In } \\ \text { his rice farming, he spent less in farm inputs } \\ \text { than what he used to spend in using inorganic } \\ \text { commercial fertilizers and pesticides. He also } \\ \text { shared the technology to others by selling the } \\ \text { natural farm inputs to other farmers. }\end{array} \\ \text { Economic } & \begin{array}{l}\text { Organic Farming } \\ \text { Reduces Farm } \\ \text { Expenses }\end{array} & \end{array}$

Most of the farmer-adopters experienced lower production cost as a result of adopting SOA technologies. To them, this is an important change. This implies that farmers would prefer to use technologies that would decrease farm expenses. If project implementers and technology promoters would like farmers to adopt their technology, they should focus their advocacy on inexpensive technologies.

Sustainable Organic Agriculture, oftentimes called organic farming, is now widely promoted in the country by different sectors, such as NonGovernment Organizations (NGOs), Local Government Units (LGUs), 
and others. To determine how the SOA technologies have been accepted and used by farmers, a study similar to this may be done in other areas covered by implementers of projects promoting SOA technologies.

This study also shows that there are at least three kinds of changes related to SOA technology adoption that are considered important by the farmers themselves. It would be interesting to conduct a study (a survey perhaps) to determine how many of the SOA technology users have experienced similar kinds of changes.

\section{REFERENCES}

CABANGISAN, M. T. 2007. Farmers'adoption and perceived benefits derived from organic rice farming in Alang-Alang, Leyte. Unpublished BS in Environmental Management Thesis. Leyte State University, Alang-Alang Campus.

CAGASAN, E. G. and M. T. H. VELASCO. 2009. Impacts of the Techno Gabay Program in Eastern Visayas, Philippines as Revealed by the Stakeholders' Stories of Significant Change. Annals of Tropical Research, 31(2).

DAGRON, G. A. 2001. Making waves: Stories of participatory communications for social change. Rockefeller Foundation, New York.

DART, J. 1999. A story approach formonitoring change in an agricultural extension project. Paper presented at the Conference of the Association for Qualitative Research, Melbourne. Retrieved on November 10, 2007 from http://www.latrobe.edu.au/aqr/offer/ papers/JDart.htm.

DART, J. J. 2000. Stories for Change: A New Model of Evaluation for Agricultural Extension Projects in Australia. Institute of Land and Food Resources, University of Melbourne, Australia. 
DAVIES, R. 1998. Order and Diversity: Representing and Assisting Organizational Learning in Non-government Aid Organizations. $\mathrm{PhD}$ Thesis, University of Wales - Swansea. Retrieved October 2005 from: http://www.mande.co.uk/thesis.htm.

DAVIES, R. and J. DART. 2005. The 'Most Significant Change' (MSC) Technique; A Guide to Its Use. Available at: www.mande.co.uk/ docs/MSCGuide.pdf

EVSOANet. 2005. Sustainable Organic Agriculture: Eastern Visayas Sustainable Organic Agriculture Network. FARMI Information Bulletin No. 01/2005, Farm and Resource Management Institute, VSU, Baybay, Leyte.

LE CORNU, R., J. PETERS, M. FOSTER, R. BARRAT, and J. STRATFOLD. 2003. Exploring perceptions of 'significant change' in reforming school cultures in South Australia. International Journal of Knowledge, Culture and Change Management 6(5):161-70.

RINGSING, B. 2003. Monitoring as a tool for learning in Ibis South America. MS Thesis, Wageningen University, Germany.

VAN DE BAN, A. W., and H. S. HAWKINS. 1996. Agricultural Extension (2nd ed). Blackwell Science Ltd., Paris.

VELARDE, G. M., R. S. GRAVOSO, E. G. CAGASAN, and C. A. GABRILLO. 2007. Most significant changes experienced by farmers from adopting rainforestation farming. Annals of Tropical Research 29(3):111-126. 